garner independence, says Rachel Jones, a postdoctoral fellow in biomedicine at the WCMC-Q. "Others give a looser rein and let their postdocs pursue their own interests as well as their supervisors," she says.

Jones credits support from her postdoc supervisor for helping her to pursue the QNRF's Young Research Scientist Experience Program, launched in May. She received an award of US $\$ 100,000$ a year for up to three years, which she views as a bridge to more substantial grants.

Many researchers would like the benefits that come with tenure, an option yet to be offered to faculty members hired at Doha branches (as opposed to those visiting from the US home campuses). This is partly explained by Gulf countries' labour and immigration laws, which frown on recruitment options implying a right of permanent residence. "Everything is set up so people who are not citizens are encouraged to leave after five or ten years," says Holste.

And Qatar and other Gulf countries rarely offer citizenship to expatriates. "A broad extension of citizenship rights to nonnationals would be extremely unpopular," says Diwan. Extensive state welfare programmes in the Gulf, along with the delicate sectarian balance to be maintained between Sunni and Shi'a Muslims, render any programme to naturalize foreigners unpalatable to most. Foreigners wishing to be hired need a Qatari sponsor (who can be an individual, a firm or a government agency). And most contracts span two to five years.

Officials at the branch campuses say that they are discussing options with the Qatar Foundation, and Al Saady notes that proposals to modernize labour laws are under way. Others in the region have proven faster than Qatar on the tenure front. The UAE, which has a thriving trade hub in Dubai, plenty of oil in Abu Dhabi and no sectarian divide, has more open labour and immigration laws than most of its neighbours.

Qatar's litany of challenges has not dissuaded enterprising researchers such as Machaca, who sees a long-term future in the small state. "As a scientist, what do I need? To do cutting-edge science, to publish it, and hopefully in the long term to be able to commercialize it. And of course you want your family to be happy," he says. "Can I do this in Doha? Absolutely."

Waleed Al-Shobakky is a freelance writer based in Doha.

\section{CORRECTION}

The story 'A helping hand' (Nature 468, 721-723; 2010) inadvertently implied that Anuj Kapadia is a clinical radiologist. $\mathrm{He}$ is an assistant professor of radiology.

\title{
DIVISION OF LABOUR
}

Proportion of US doctorate recipients with definite post-graduation employment commitments in the United States, by field and sector.

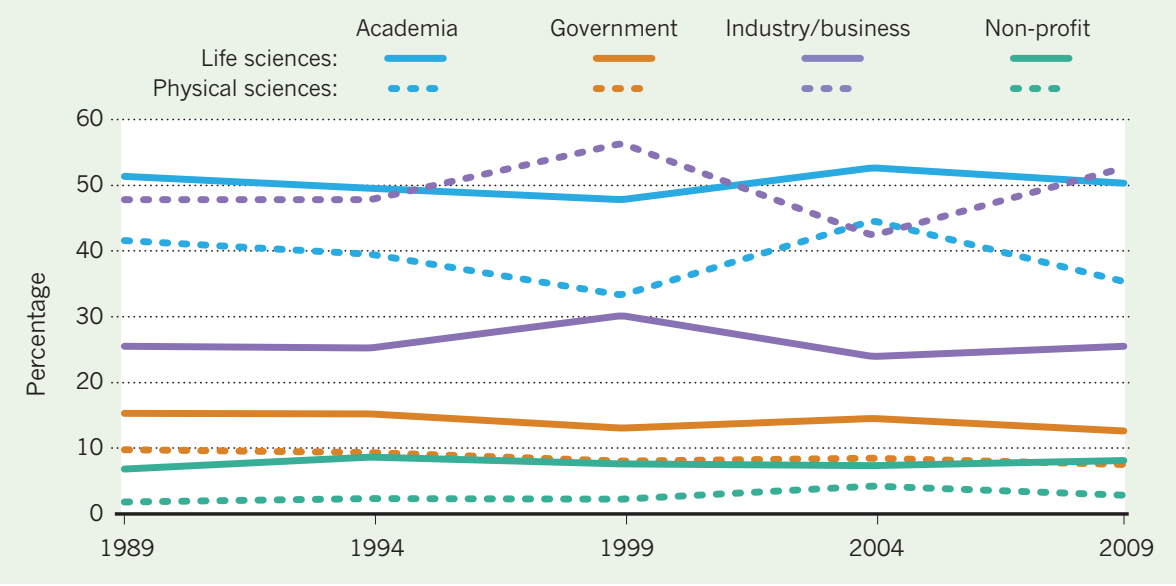

EMPLOYMENT TRENDS

\section{Drawn to academia}

\section{Low salaries and elusive tenure didn't dim the appeal of self-directed research for US scientists last year.}

\section{BY KAREN KAPLAN}

$\mathrm{D}$ espite a struggling economy, lower salaries and an increase in adjunct and contingent positions, a higher proportion of US scientists headed to academia than to any other sector in 2009, according to numbers from the US National Science Foundation (NSF). Published on 3 December, Doctorate Recipients from US Universities: 2009 includes salary data for the first time in the annual report's 43-year history.

Even with universities offering much lower salaries than industry, half of all life-sciences $\mathrm{PhD}$ recipients who had secured jobs said that they were entering academic positions, according to the survey. This proportion, which has varied little since 1989, is a testament to the powerful lure of positions that enable self-directed research, say analysts. "Many scientists want the independence of working on their own research, rather than on what's handed to them," says Mark Fiegener, an NSF programme manager based in Arlington, Virginia. The NSF received survey responses from 420 US universities and 49,562 $\mathrm{PhD}$ recipients.

The industrial sector proffered the highest median early-career salaries - up to US\$95,000 in some instances - in most disciplines in the physical and life sciences. The median for an academic post in biological sciences was $\$ 45,000$, compared with $\$ 85,000$ for a commercial position in the same subfield, including biochemistry, marine biology and zoology. Other fields had similar disparities.
Academia dominated life-sciences employment in 2009, but industry was stronger for physical scientists, despite changes to job numbers since 2008 that run counter to five-year trends and could be due to pharmaceutical layoffs (see 'Division of labour'). Richard Freeman, an economist at Harvard University in Cambridge, Massachusetts, attributes the five-year trend in part to hiring increases at drug-making and chemical firms. He says that mergers and layoffs will continue to slow the field down.

Industry's constraints will put pressure on academia, which is already pinched by the recession, says Marc Bousquet, an associate professor at Santa Clara University in California who is on the executive council of the American Association of University Professors. Scientists in all fields will struggle to find academic posts - and few of those available will be tenure-track, he says.

The report also uncovers significant pay differences between early-career men and women with PhDs. Men earned up to $\$ 10,000$ more than women in nearly all fields except astronomy, where they earned $\$ 30,000$ more. Joan Herbers, president of the Association for Women in Science in Alexandria, Virginia, says women need help learning to negotiate salaries and raises. "When you start out at a lower salary," she says, "that dogs you for the rest of your career."

Postdocs earned $\$ 37,500$ to $\$ 45,000$, which, given their average schedule, Freeman estimates, works out to $\$ 12.50$ to $\$ 15$ an hour. "Some of the best and brightest people in our country earn a pittance," says Freeman. 